\title{
Article
}

\section{Increased exposure to pesticides and colon cancer: Early evidence in Brazil}

Martin, Francis L, Martinez, Edson Z., Stopper, Helga, Garcia, Sergio Britto, Uyemura, Sergio Akira and Kannen, Vinicius

Available at http://clok.uclan.ac.uk/23305/

Martin, Francis L ORCID: 0000-0001-8562-4944, Martinez, Edson Z., Stopper, Helga, Garcia, Sergio Britto, Uyemura, Sergio Akira and Kannen, Vinicius (2018) Increased exposure to pesticides and colon cancer: Early evidence in Brazil. Chemosphere, 209 . pp. 623-631. ISSN 0045-6535

It is advisable to refer to the publisher's version if you intend to cite from the work. http://dx.doi.org/10.1016/j.chemosphere.2018.06.118

For more information about UCLan's research in this area go to http://www.uclan.ac.uk/researchgroups/ and search for <name of research Group>.

For information about Research generally at UCLan please go to http://www.uclan.ac.uk/research/

All outputs in CLoK are protected by Intellectual Property Rights law, including Copyright law. Copyright, IPR and Moral Rights for the works on this site are retained by the individual authors and/or other copyright owners. Terms and conditions for use of this material are defined in the policies page.

\section{CLoK}

Central Lancashire online Knowledge www.clok.uclan.ac.uk

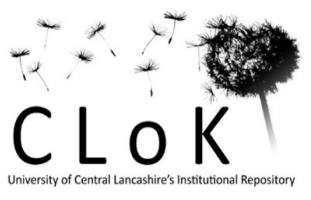




\section{Accepted Manuscript}

Increased exposure to pesticides and colon cancer: Early evidence in Brazil

Francis L. Martin, Edson Z. Martinez, Helga Stopper, Sergio Britto Garcia, Sergio

Akira Uyemura, Vinicius Kannen

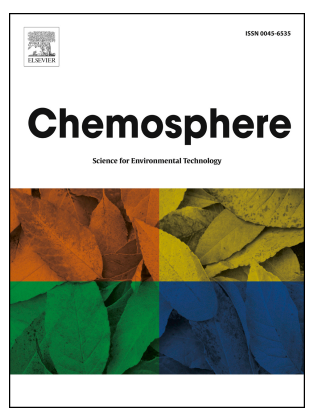

PII:

S0045-6535(18)31193-7

DOI:

10.1016/j.chemosphere.2018.06.118

Reference: CHEM 21650

To appear in: $E C S N$

Received Date: 15 April 2018

Revised Date: 14 June 2018

Accepted Date: 17 June 2018

Please cite this article as: Martin, F.L., Martinez, E.Z., Stopper, H., Garcia, S.B., Uyemura, S.A., Kannen, V., Increased exposure to pesticides and colon cancer: Early evidence in Brazil, Chemosphere (2018), doi: 10.1016/j.chemosphere.2018.06.118.

This is a PDF file of an unedited manuscript that has been accepted for publication. As a service to our customers we are providing this early version of the manuscript. The manuscript will undergo copyediting, typesetting, and review of the resulting proof before it is published in its final form. Please note that during the production process errors may be discovered which could affect the content, and all legal disclaimers that apply to the journal pertain. 


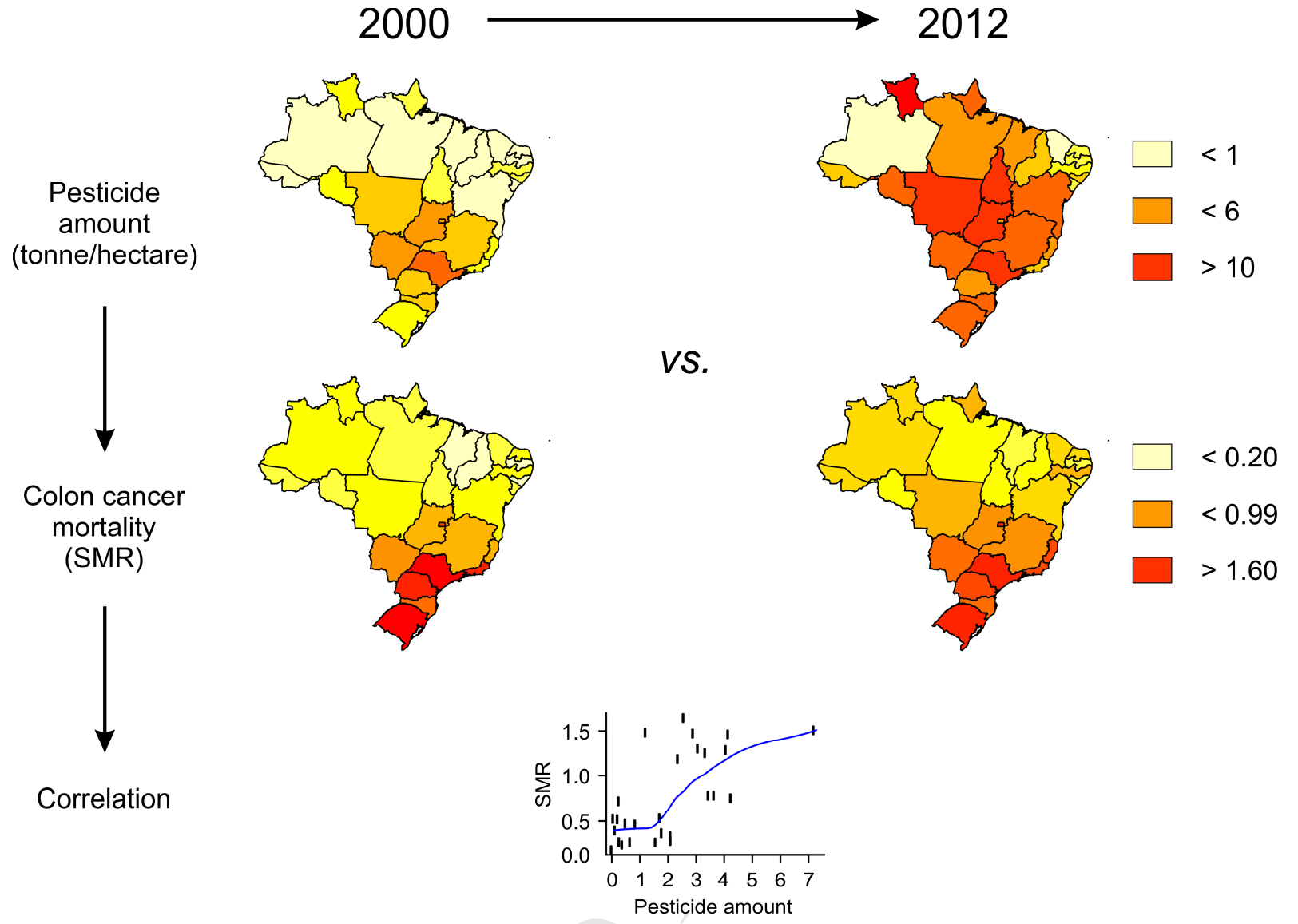


1 Increased exposure to pesticides and colon cancer: early evidence in Brazil

2

3 Francis L. Martin ${ }^{1}$, Edson Z. Martinez ${ }^{2}$, Helga Stopper $^{3}$, Sergio Britto Garcia ${ }^{4}$,

4 Sergio Akira Uyemura ${ }^{5}$, Vinicius Kannen ${ }^{5}$

5

$6{ }^{1}$ School of Pharmacy and Biomedical Sciences, University of Central Lancashire, 7 Preston PR1 2HE, United Kingdom;

Running title: Pesticide and colon cancer

${ }^{2}$ Department of Social Medicine, University of Sao Paulo, Ribeirao Preto, Brazil;

${ }^{3}$ Department of Toxicology, University of Wuerzburg, Wuerzburg, Germany;

${ }^{4}$ Department of Pathology, University of Sao Paulo, Ribeirao Preto, Brazil;

${ }^{5}$ Department of Toxicology, Bromatology, and Clinical Analysis, University of Sao Paulo, Ribeirao Preto, Brazil. (1)

Corresponding Author:

Tel +55 (16) 3315.9133; Fax: +55 (16) 33154725;

E-mail: vinicius.kannen@fcfrp.usp.br. 


\section{ABSTRACT}

Environmental factors may increase colon cancer (CC) risk. It has been suggested that pesticides could play a significant role in the etiology of this malignancy. As agriculture is one of the mainstays of the Brazilian economy, this country has been the largest pesticides consumer worldwide. The CC burden is also increasing in Brazil. Herein, we examined data from the Brazilian Federal Government to determine whether CC mortality and pesticide consumption may be associated. Database of the Ministry of Health provided CC mortality data in Brazil, while pesticides use was accessed at the website of Brazilian Institute of Environment and Renewable Natural Resources. The CC mortality in the Brazilian states was calculated as standard mortality rates (SMR). All Bayesian analysis was performed using a Markov chain Monte Carlo method in WinBUGS software. We observed that colon cancer mortality has exhibited a steady increase for more than a decade, which correlated with the amount of sold pesticides in the country. Both observations are concentrated in the Southern and the Southeast regions of Brazil. Although ecological studies like ours have methodological limitations, the current dataset suggests the possibility that pesticide exposure may be a risk factor for colon cancer. It warrants further investigation.

Keywords: Xenobiotics; carcinogens; environment; tumors; intestines 


\section{Introduction}

Colon cancer (CC) has afflicted humans for millennia. Chronic exposure to certain environmental factors appears to be the key to better understanding the etiology of this malignancy (David and Zimmerman, 2010). Over-nutrition and sedentary lifestyle may also be responsible for up to $75 \%$ of cancers today (Nebert and Dalton, 2006; David and Zimmerman, 2010). Notably, CC is one of the leading cause of cancer-related deaths (Torre et al., 2015). By 2030, developing countries are expected to exhibit a sharp increase in CC cases (Arnold et al., 2016). Also, it should be pointed out that recent epidemiological trends highlight that the $\mathrm{CC}$ burden is shifting towards a younger population (de Magalhaes, 2013; Siegel et al., 2014).

Cancer risk, including CC, appears to be profoundly influenced by environmental factors (Wu et al., 2016). Thus, CC etiology is complex, meaning that a multiple of environmental factors may cause this disease. One of many hazardous and carcinogenic factors promoting malignancies, pesticides have been suggested by the International Agency for Research on Cancer (IARC) to increase cancer risk in humans (Guyton et al., 2015; Guyton et al., 2016). Extensive epidemiological studies support the idea that pesticides are a risk factor for solid tumors (Parron et al., 2014). There has also been some evidence that pesticides promote CC in both humans and rodents (Soliman et al., 1997; Tellez-Banuelos et al., 2016; Hong et al., 2017). It seems feasible that pesticides contaminate human food sources (Nagao and Sugimura, 1993; Lodovici et al., 1997; Sakita et al., 2017), a fact that may be related to increased cancer risk (Arrebola et al., 2015). Another point underlying to study the relationship between pesticides and cancer 
must be considered: disease incidence is increasing dramatically (Lodovici et al., 1997; Soliman et al., 1997; Agudo et al., 2009; Andreotti et al., 2010; Boccolini Pde et al., 2013; Parron et al., 2014; Arrebola et al., 2015; Carnero et al., 2015; Coggon et al., 2015; Guyton et al., 2015; Guyton et al., 2016; Tellez-Banuelos et al., 2016; Hong et al., 2017).

Furthermore, the lack of epidemiological and experimental data that accurately correlate CC incidence with detection of individual cancer initiators impairs our current ability to determine the impact of environmental factors on the CC development in humans (Tomasetti and Vogelstein, 2015). For instance, various environmental pollutants were reported to induce DNA damage and adducts, but the precise evolution of such genomic damages into mutations that promote CC remains unknown (Tomasetti and Vogelstein, 2015; Poirier, 2016). Then, it should be considered that instead of those DNA-damaging effects induced by initiators, endogenous and exogenous cancer promoters are classically determined to lead mutated cells towards clonal expansion, enabling them to collect further genomic changes by either high proliferative activity or new carcinogenic hits (Irigaray and Belpomme, 2010). Rather than binding to DNA, a cancer promoter usually activates transcriptional and epigenetic mechanisms that induce proliferation but inhibit apoptosis (Irigaray and Belpomme, 2010; Engstrom et al., 2015). Such mechanistic activity has for long been known to induce proliferation intrinsic errors leading to mutations and the development of CC (Ames and Gold, 1990; Bartkova et al., 2005; Gorgoulis et al., 2005). Interestingly, pesticides may act either as carcinogens or cancer promoters (Agudo et al., 2009; Andreotti et al., 2010; Arrebola et al., 2015; Carnero et al., 2015; Coggon et al., 
2015). Of note is the fact that Brazil has been the most significant consumer of pesticides worldwide for years (Boccolini Pde et al., 2013). Recently, we have hypothesized that pesticides could impact on the CC risk (Uyemura et al., 2017). Herein, we propose an association between increased CC mortality and pesticide consumption in Brazil. This could suggest that pesticides alter the risk of $\mathrm{CC}$ in a human population.

\section{Materials and methods}

\subsection{Collection of public data}

CC mortality (http://www2.datasus.gov.br/DATASUS/index.php?area=0205) was collected from the database of the Ministry of Health. The quantity of pesticides (tonnes) sold within the country was downloaded from the website of the Brazilian Institute of Environment and Renewable Natural Resources (http://dados.contraosagrotoxicos.org/pt PT/dataset/comercializacao-ibama-2014; http://www.ibge.gov.br/). Complementary data on pesticides and farmed land area for each Brazilian state $\left(\mathrm{Km}^{2}\right)$ were collected from the Brazilian Institute of Geography and Statistics (http://www.ibge.gov.br/).

\subsection{Statistical analyses}

The CC mortality in the Brazilian states was calculated as standard mortality rates (SMR). Further information on SMR can be found in a previous report authored by Ulm (Ulm, 1990). We determined SMR to be the ratio of observed mortality to expected mortality adjusted for age and gender group. An SMR value $>1$ indicates excessive mortality. Expected numbers of death were calculated using age and 
121

122

123

124

125

126

127

128

129

130

131

132

$$
\operatorname{SMR}(p, s, t)=\frac{Y(p, s, t)}{E(p, s, t)}
$$

133

$$
Y(p, s, t) \mid \mu(p, s, t), E(p, s, t) \sim \text { Poisson }[E(p, s, t) \times \mu(p, s, t)]
$$

gender-specific mortality rates for the Brazilian general population (assumed to be the standard population). Within this approach, w(s,t,f) was the death rate for the Brazilian population at the year $t(t=1$ if $2000, t=2$ if 2001 , and so on) considering gender $s$ ( $s=1$ if women and $s=2$ if man) and age group $f(f=1$ if $<50$ y old, $f=2$ if 50 to $59 \mathrm{y}, f=3$ if 60 to $69 \mathrm{y}, f=4$ if 70 to $79 \mathrm{y}$ and $f=5$ if $\geq 80 \mathrm{y}$ ). The expected number of death for each Brazilian state $p(p=1, \ldots, 27)$ in the year $(t)$ according to the gender (s) is given by:

$$
E(p, s, t)=\sum_{f=1}^{5} w(s, t, f) \times m(p, s, t, f)
$$

where $m(p, s, t, f)$ is the number of inhabitants of the state (p) with gender $(s)$ at the year (t) and group age (f). The SMR is thus given by:

where $Y(p, s, t)$ is corresponding observed mortality. Spatio-temporally smoothed SMR values were obtained from a Bayesian model based on the Poisson distribution. This statistical model is given by: 
where $\mu(p, s, t)=\exp \left[\alpha_{0}+\alpha_{s p}+\omega(p, s, t)\right]$ is the parameter that describes the SMR, $\alpha_{0}$ is an intercept, $\alpha_{s p}$ are bivariate random effects that capture spatial dependence in the data $(s=1,2, p=1, \ldots, 27)$ and $\omega(p, s, t)$ models the longitudinal trend of annual mortality rate for the federation unit $p$ and gender $s$, considering a multivariate Gaussian process with a mean vector $5 \times 1$ with all components equal to zero and a given covariance function. In the Bayesian analysis, it was assumed that $\alpha_{s p}$ follows a conditionally bivariate autoregressive (CAR) structure and $\alpha_{0}$ follows a non-informative normal distribution with mean zero and a large variance. Then, we verified the association between the HDI of each Brazilian state and the corresponding SMR, for which a Bayesian model was fitted to the data. Thus, $\mu(p, s, t)$ was replaced by:

$$
\mu(p, s, t)=\exp \left[\alpha_{0}+\alpha_{s p}+\beta_{s t} x(p)\right]
$$

where $x(p)$ is the amount of sold pesticide (measured in tonnes) recorded in each Brazilian state $(p)$ at the year 2000 , divided by its respective total cultivated area in hectares (including permanent and temporary crops) and multiplied by 1,000 , and $\beta_{s t}$ is the corresponding effect. Credible intervals for $\beta_{s t}$ that do not include zero indicates a significant correlation between the amount of sold pesticide and the mortality rate. Credible intervals are the Bayesian analogues to the traditional $95 \%$ confidence intervals. In all Bayesian analysis, the posterior distributions were simulated using a Markov chain Monte Carlo (MCMC) method in WinBUGS software. 


\section{Results}

$\mathrm{CC}$ has not only been suggested to be one of the commonest malignancy types in Western countries (Torre et al., 2015) but also that its incidence and mortality may increase throughout the next decade in developing countries (Arnold et al., 2016). This notion inspired us to apply the Bayesian model to calculate SMR values for CC mortality in the Brazilian population. Heatmaps revealed that mortality by CC mainly occurred in the Southern Brazilian states (Figure 1 and 2).

Environmental factors are well-known able of increasing cancer risk (Wu et al., 2016). In addition, the IARC has suggested that pesticide can promote human risk of developing different types of cancer (Guyton et al., 2015; Guyton et al., 2016). In developing countries, some research groups report that pesticides may increase cancer incidence (Soliman et al., 1997; Fonnum and Mariussen, 2009; Yi, 2013; Arrebola et al., 2015). Herein, we analyzed the quantity of pesticide sold in Brazil. We should note that these records were reported by the Federal Government in tonnes for each state, and are the most accurate dataset available to the public. To provide a better perspective of pesticide distribution in each Federal unit, we rated pesticide values by the total cultivated area that was officially reported for each of those Brazilian states. We observed a dramatic increase in pesticide usage from 2000 to 2012 within the country, mainly in the Southern, Southeast and Central-West regions of Brazil (Figure 3).

Next, we examined whether both events were correlated in the Brazilian population. We found an increase in SMR values correlating with the amount of pesticide sold by 2000 in Brazil (Figure 4 and 5). Smoothed curves fitted by loess were added on each graph. Moreover, it shows $95 \%$ credible intervals for the 
effects $\left(\beta_{\text {st }}\right)$ of the amount of sold pesticide on the SMR values for each year $(t)$ and gender $(s)$, obtained from the Bayesian spatiotemporal regression models. From 2000 to 2007, the credible intervals do not contain zero, thus suggesting a significant effect of the amount of sold pesticide recorded in each Brazilian state on their corresponding SMR for CC (Figure 6).

\section{Discussion}

We should initially consider that some environmental chemicals damage the DNA, whereas other promote the expansion of mutated cells during the development of CC (Lawrence et al., 2013; Tomasetti and Vogelstein, 2015; Poirier, 2016), meaning that we can no longer hypothesize that only DNA damaging compounds impact on the cancer risk in humans. Indeed, it seems that the mutation rate intrinsic to mitosis might be sufficient in invoking oncogenic changes in the rapidly dividing colonic epithelial cell population (Bartkova et al., 2005; Gorgoulis et al., 2005). This was initially observed in classical experiments of rodents exposed to cancer promoters (Ames and Gold, 1990). Persistent epithelial self-renewal requires precise molecular regulation of proliferation in component cells that is, consequently, prey to corruption by environmental and mutational factors. It is, therefore, no surprise that the majority of cancers originated in epithelial tissue are due to somatic mutations that deregulate the molecular constraints on cell pluripotency and proliferation (Lawrence et al., 2013; Tomasetti and Vogelstein, 2015; Vogelstein and Kinzler, 2015).

Manmade compounds (xenobiotics) can access the human body via multiple routes, each modifying the risk of cancer (Sakita et al., 2017; Uyemura et al., 
212

213

214

215

216

217

218

219

220

221

222

2017). This requires that the increasingly large number of chemicals whose cancer-causing effects remain unknown should be taken into account while discussing the impact of environmental factors on CC risk (Guha et al., 2016). Indeed, most pesticides might have endocrine-disrupting and metabolic effects, as well as bio-accumulating in the human body (Irigaray and Belpomme, 2010; Soto and Sonnenschein, 2010; Walker and Gore, 2011; Ellsworth et al., 2015; Espin Perez et al., 2015; Maqbool et al., 2016). It means that whether pesticides interact at low levels and may increase the risk of cancer, their activity does not need to be simultaneous or continuous. Combining several exposures to different pesticides at multiple time-points could, thus, induce far greater cancer-related effects than single compounds in humans (Goodson et al., 2015).

The massive number of modern xenobiotics has made almost impossible to determine what their precise impact on human cancer risk is (Bouvard et al., 2015; Goodson et al., 2015). For instance, a research group analyzed 6000 human-made compounds and found that $16.3 \%$ of those chemicals were pesticides, from which less than 1\% had been investigated in the context of cancer (Guha et al., 2016). Alavanja and colleagues studied the effects of 50 commonly used pesticides in 56,813 pesticide applicators and found a potential relationship between exposure to chlorpyrifos and aldicarb with the incidence of colorectal cancer (CRC) (Lee et al., 2007). A meta-analysis study suggested that aldicarb could increase the CC risk, imazethapyr may promote the cancer risk in the proximal colon region, and $\mathrm{CRC}$ risk was probably enhanced by exposure to pendimethalin, chlorpyrifos, chlordane, and toxaphene (Alexander et al., 2012). Considering the complex CC etiology together with the little number of epidemiological and experimental data 
236

237

238

239

240

241

242

243

244

245

246

247

248

249

250

251

252

253

254

255

256

257

258

259

correlating $\mathrm{CC}$ development with the environmental pollution by pesticides becomes clear that further efforts are required to clarify this matter.

In Tunisia, foodstuffs containing pesticides were suggested to increase the risk of breast cancer in women (Arrebola et al., 2015). Different Brazilian research groups have reported high-pesticide levels in human milk in the country (Matuo et al., 1992; Beretta and Dick, 1994; Dorea et al., 1997). Pesticide levels in bovine milk have been reported to exceed safety standards in the Midwest region of Brazil (Avancini et al., 2013). Then, public data from the Brazilian National Health Surveillance Agency (Anvisa; http://portal.anvisa.gov.br/en/programa-de-analisede-registro-de-agrotoxicos-para) show that $20 \%$ of food samples analyzed between 2013 and 2015 were unsafe for human use. In 2013, Meyer and colleagues revealed that pesticides could be related to increased non-Hodgkin's lymphoma mortality found in Brazil (Boccolini Pde et al., 2013). Koifman and colleagues hypothesized that cancer-related mortality in Brazilian farm workers could be related to their exposure to pesticides from 1979 to 1998 (Meyer et al., 2003). Meyer and colleagues suggested that the amount of pesticides selected in 1985 could be related to breast, prostate, and ovarian cancer mortality ten years later (Koifman S., 2002). In Martinique, pesticides increased the risk of prostate cancer (Landau-Ossondo et al., 2009). In South-Korea, pesticides increased CC risk (Fonnum and Mariussen, 2009; Yi, 2013). Indeed, high-pesticide serum levels were detected in CC patients in Egypt (Soliman et al., 1997). In rats, pesticides increased the risk of CC (Hong et al., 2017). Then, another research group suggested that pesticides might increase $\mathrm{CC}$ risk by promoting inflammation in the colon (Tellez-Banuelos et al., 2016). 
Although there has been some evidence that pesticides could be a risk

261

262

263

264

265

266 factor for CC (Soliman et al., 1997; Lee et al., 2007; Fonnum and Mariussen, 2009; Alexander et al., 2012; Yi, 2013; Hong et al., 2017), other limitations in studying the effects of these chemicals in cancer have to be considered. Carcinogenic effects of human-made pollutants usually require protracted exposure to be detectable. For instance, asbestos-related effects increasing lung mesothelioma have been reported to take over 63 years to develop (Hodgson et al., 2005). However, we should also consider that asbestos has an established effect in promoting this type of malignancy in the lungs (Hodgson et al., 2005), while the complex activity of multiple pesticides in different types of cancer makes almost impossible to suggest which pesticide directly increases the CC risk in the human population. Moreover, other confounding factors could also have similar effects promoting CC risk. For instance, dietary factors seemed to be one of the main risk factors promoting this disease in humans (Sakita et al., 2017). Notably, a 10\% increase in the intake of ultra-processed food furthered by $10 \%$ the cancer risk in humans (Fiolet et al., 2018). In Brazil, the risk of developing CRC was related to the high consumption of meat (Angelo et al., 2016). Here, we should also consider that human food sources have been suggested to be contaminated by pesticides in Brazil (Matuo et al., 1992; Beretta and Dick, 1994; Dorea et al., 1997; Avancini et al., 2013; Uyemura et al., 2017). This scenario is quite severe since some types of food with known carcinogenic potential could have a more hazardous effect if they contained pesticides in their composition. Indeed, we do not claim to have found that pesticides cause CC mortality in Brazil, but current evidence should not be ignored and requires further study. 
Nevertheless, from our perspective, the CC mortality rates in the Brazilian

285

286

287

288

289

290

291

292

293

294 state Amapá, located at the North region of the country, seems to be an outlier. CC-related death numbers varied from the lowest to the highest rates in the country by 2005 . This increase reversed over the subsequent period. Lima and Queiroz analyzed the Brazilian death registry system and found that completeness of death registration in this state was one of the poorest in the country (Lima and Queiroz, 2014). Hence, we advise future studies to have careful consideration on this matter while investigating mortality rates during this period in that Brazilian state.

\section{Conclusion}

We believe that protracted exposure to pesticide may be a potential risk factor for CC. This fact requires urgent attention from the Federal Government monitoring the exposure of Brazilians to such chemicals. Whereas authorities must oversee the activity of multinational agrochemical and agricultural biotechnology corporations, as well as pesticide usage in agriculture, farmers should be informed by awareness programs to improve their product quality without harming the human population with high pesticide residue levels in the environment and food.

\section{Conflict of interest statement}

The authors disclose that no competing interests exist.

\section{Acknowledgements}


307 The authors disclose receipt of the following financial support for the development

308 of this investigation: Sao Paulo Research Foundation (FAPESP; 2014/06428-5;

309 2015/01723-1). The funder had no role in the study design, data collection,

310 analysis, decision to publish, or preparation of the manuscript.

\section{Authors' role}

Study concept and design: VK; Acquisition of data: VK and EZM; Statistical analysis: EZM; Analysis and interpretation of data: All; Drafting the first version of the manuscript: FLM and VK; Critical revision of the manuscript: All; Obtained funding: VK; Study supervision: FLM, EZM and VK.

\section{References}

Agudo, A., Goni, F., Etxeandia, A., Vives, A., Millan, E., Lopez, R., Amiano, P., Ardanaz, E., Barricarte, A., Chirlaque, M.D., Dorronsoro, M., Jakszyn, P., Larranaga, N., Martinez, C., Navarro, C., Rodriguez, L., Sanchez, M.J., Tormo, M.J., Gonzalez, C.A., 2009. Polychlorinated biphenyls in Spanish adults: determinants of serum concentrations. Environmental research 109, 620-628. Alexander, D.D., Weed, D.L., Mink, P.J., Mitchell, M.E., 2012. A weight-of-evidence review of colorectal cancer in pesticide applicators: the agricultural health study and other epidemiologic studies. International archives of occupational and

327 environmental health $85,715-745$.

328 Ames, B.N., Gold, L.S., 1990. Too many rodent carcinogens: mitogenesis 329 increases mutagenesis. Science 249, 970-971. 
330

331

332

333

334

335

336

337

Andreotti, G., Hou, L., Beane Freeman, L.E., Mahajan, R., Koutros, S., Coble, J., Lubin, J., Blair, A., Hoppin, J.A., Alavanja, M., 2010. Body mass index, agricultural pesticide use, and cancer incidence in the Agricultural Health Study cohort. Cancer causes \& control : CCC 21, 1759-1775.

Angelo, S.N., Lourenco, G.J., Magro, D.O., Nascimento, H., Oliveira, R.A., Leal, R.F., Ayrizono Mde, L., Fagundes, J.J., Coy, C.S., Lima, C.S., 2016. Dietary risk factors for colorectal cancer in Brazil: a case control study. Nutrition journal 15, 20. Arnold, M., Sierra, M.S., Laversanne, M., Soerjomataram, I., Jemal, A., Bray, F., 2016. Global patterns and trends in colorectal cancer incidence and mortality. Gut. Arrebola, J.P., Belhassen, H., Artacho-Cordon, F., Ghali, R., Ghorbel, H., Boussen, H., Perez-Carrascosa, F.M., Exposito, J., Hedhili, A., Olea, N., 2015. Risk of female breast cancer and serum concentrations of organochlorine pesticides and polychlorinated biphenyls: a case-control study in Tunisia. The Science of the total environment 520, 106-113.

Avancini, R.M., Silva, I.S., Rosa, A.C., Sarcinelli Pde, N., de Mesquita, S.A., 2013. Organochlorine compounds in bovine milk from the state of Mato Grosso do SulBrazil. Chemosphere 90, 2408-2413.

Bartkova, J., Horejsi, Z., Koed, K., Kramer, A., Tort, F., Zieger, K., Guldberg, P., Sehested, M., Nesland, J.M., Lukas, C., Orntoft, T., Lukas, J., Bartek, J., 2005. DNA damage response as a candidate anti-cancer barrier in early human tumorigenesis. Nature 434, 864-870.

Beretta, M., Dick, T., 1994. Organochlorine compounds in human milk, Porto Alegre, Brazil. Bulletin of environmental contamination and toxicology 53, 357-360. 
353 Boccolini Pde, M., Boccolini, C.S., Chrisman Jde, R., Markowitz, S.B., Koifman, S.,

354 Koifman, R.J., Meyer, A., 2013. Pesticide use and non-Hodgkin's lymphoma 355 mortality in Brazil. International journal of hygiene and environmental health 216, $356 \quad 461-466$.

357 Bouvard, V., Loomis, D., Guyton, K.Z., Grosse, Y., Ghissassi, F.E., Benbrahim358 Tallaa, L., Guha, N., Mattock, H., Straif, K., International Agency for Research on 359 Cancer Monograph Working, G., 2015. Carcinogenicity of consumption of red and 360 processed meat. Lancet Oncol.

361 Carnero, A., Blanco-Aparicio, C., Kondoh, H., Lleonart, M.E., Martinez-Leal, J.F., 362 Mondello, C., Ivana Scovassi, A., Bisson, W.H., Amedei, A., Roy, R., Woodrick, J., 363 Colacci, A., Vaccari, M., Raju, J., Al-Mulla, F., Al-Temaimi, R., Salem, H.K., 364 Memeo, L., Forte, S., Singh, N., Hamid, R.A., Ryan, E.P., Brown, D.G., Wise, J.P., 365 Sr., Wise, S.S., Yasaei, H., 2015. Disruptive chemicals, senescence and 366 immortality. Carcinogenesis 36 Suppl 1, S19-37.

367 Coggon, D., Ntani, G., Harris, E.C., Jayakody, N., Palmer, K.T., 2015. Soft tissue 368 sarcoma, non-Hodgkin's lymphoma and chronic lymphocytic leukaemia in workers 369 exposed to phenoxy herbicides: extended follow-up of a UK cohort. Occupational 370 and environmental medicine $72,435-441$.

371 David, A.R., Zimmerman, M.R., 2010. Cancer: an old disease, a new disease or 372 something in between? Nat Rev Cancer 10, 728-733.

373 de Magalhaes, J.P., 2013. How ageing processes influence cancer. Nat Rev 374 Cancer 13, 357-365. 
375 Dorea, J.G., Granja, A.C., Romero, M.L., 1997. Pregnancy-related changes in fat mass and total DDT in breast milk and maternal adipose tissue. Annals of nutrition \& metabolism 41, 250-254.

Ellsworth, R.E., Mamula, K.A., Costantino, N.S., Deyarmin, B., Kostyniak, P.J., Chi, L.H., Shriver, C.D., Ellsworth, D.L., 2015. Abundance and distribution of polychlorinated biphenyls (PCBs) in breast tissue. Environmental research 138, 291-297.

Engstrom, W., Darbre, P., Eriksson, S., Gulliver, L., Hultman, T., Karamouzis, M.V., Klaunig, J.E., Mehta, R., Moorwood, K., Sanderson, T., Sone, H., Vadgama, P., Wagemaker, G., Ward, A., Singh, N., Al-Mulla, F., Al-Temaimi, R., Amedei, A., Colacci, A.M., Vaccari, M., Mondello, C., Scovassi, A.I., Raju, J., Hamid, R.A., Memeo, L., Forte, S., Roy, R., Woodrick, J., Salem, H.K., Ryan, E.P., Brown, D.G., Bisson, W.H., 2015. The potential for chemical mixtures from the environment to enable the cancer hallmark of sustained proliferative signalling. Carcinogenesis 36 Suppl 1, S38-60.

Espin Perez, A., de Kok, T.M., Jennen, D.G., Hendrickx, D.M., De Coster, S., Schoeters, G., Baeyens, W., van Larebeke, N., Kleinjans, J.C., 2015. Distinct genotype-dependent differences in transcriptome responses in humans exposed to environmental carcinogens. Carcinogenesis.

Fiolet, T., Srour, B., Sellem, L., Kesse-Guyot, E., Alles, B., Mejean, C., Deschasaux, M., Fassier, P., Latino-Martel, P., Beslay, M., Hercberg, S., Lavalette, C., Monteiro, C.A., Julia, C., Touvier, M., 2018. Consumption of ultra-processed foods and cancer risk: results from NutriNet-Sante prospective cohort. Bmj 360, k322. 
399

400

401

402

403

404

405

406

407

408

409

410

411

412

413

414

415

416

417

418

419

420

421

422

Fonnum, F., Mariussen, E., 2009. Mechanisms involved in the neurotoxic effects of environmental toxicants such as polychlorinated biphenyls and brominated flame retardants. J Neurochem 111, 1327-1347.

Goodson, W.H., 3rd, Lowe, L., Carpenter, D.O., Gilbertson, M., Manaf Ali, A., Lopez de Cerain Salsamendi, A., Lasfar, A., Carnero, A., Azqueta, A., Amedei, A., Charles, A.K., Collins, A.R., Ward, A., Salzberg, A.C., Colacci, A., Olsen, A.K., Berg, A., Barclay, B.J., Zhou, B.P., Blanco-Aparicio, C., Baglole, C.J., Dong, C., Mondello, C., Hsu, C.W., Naus, C.C., Yedjou, C., Curran, C.S., Laird, D.W., Koch, D.C., Carlin, D.J., Felsher, D.W., Roy, D., Brown, D.G., Ratovitski, E., Ryan, E.P., Corsini, E., Rojas, E., Moon, E.Y., Laconi, E., Marongiu, F., Al-Mulla, F., Chiaradonna, F., Darroudi, F., Martin, F.L., Van Schooten, F.J., Goldberg, G.S., Wagemaker, G., Nangami, G.N., Calaf, G.M., Williams, G., Wolf, G.T., Koppen, G., Brunborg, G., Lyerly, H.K., Krishnan, H., Ab Hamid, H., Yasaei, H., Sone, H., Kondoh, H., Salem, H.K., Hsu, H.Y., Park, H.H., Koturbash, I., Miousse, I.R., Scovassi, A.I., Klaunig, J.E., Vondracek, J., Raju, J., Roman, J., Wise, J.P., Sr., Whitfield, J.R., Woodrick, J., Christopher, J.A., Ochieng, J., Martinez-Leal, J.F., Weisz, J., Kravchenko, J., Sun, J., Prudhomme, K.R., Narayanan, K.B., CohenSolal, K.A., Moorwood, K., Gonzalez, L., Soucek, L., Jian, L., D'Abronzo, L.S., Lin, L.T., Li, L., Gulliver, L., McCawley, L.J., Memeo, L., Vermeulen, L., Leyns, L., Zhang, L., Valverde, M., Khatami, M., Romano, M.F., Chapellier, M., Williams, M.A., Wade, M., Manjili, M.H., Lleonart, M.E., Xia, M., Gonzalez, M.J., Karamouzis, M.V., Kirsch-Volders, M., Vaccari, M., Kuemmerle, N.B., Singh, N., Cruickshanks, N., Kleinstreuer, N., van Larebeke, N., Ahmed, N., Ogunkua, O., Krishnakumar, P.K., Vadgama, P., Marignani, P.A., Ghosh, P.M., Ostrosky-Wegman, P., 
423 Thompson, P.A., Dent, P., Heneberg, P., Darbre, P., Sing Leung, P., Nangia-

424 Makker, P., Cheng, Q.S., Robey, R.B., Al-Temaimi, R., Roy, R., Andrade-Vieira, 425 R., Sinha, R.K., Mehta, R., Vento, R., Di Fiore, R., Ponce-Cusi, R., Dornetshuber426 Fleiss, R., Nahta, R., Castellino, R.C., Palorini, R., Abd Hamid, R., Langie, S.A., 427 Eltom, S.E., Brooks, S.A., Ryeom, S., Wise, S.S., Bay, S.N., Harris, S.A., 428 Papagerakis, S., Romano, S., Pavanello, S., Eriksson, S., Forte, S., Casey, S.C., 429 Luanpitpong, S., Lee, T.J., Otsuki, T., Chen, T., Massfelder, T., Sanderson, T., 430 Guarnieri, T., Hultman, T., Dormoy, V., Odero-Marah, V., Sabbisetti, V., Maguer431 Satta, V., Rathmell, W.K., Engstrom, W., Decker, W.K., Bisson, W.H., Rojanasakul, 432 Y., Luqmani, Y., Chen, Z., Hu, Z., 2015. Assessing the carcinogenic potential of 433 low-dose exposures to chemical mixtures in the environment: the challenge ahead. 434 Carcinogenesis 36 Suppl 1, S254-296.

435 Gorgoulis, V.G., Vassiliou, L.V., Karakaidos, P., Zacharatos, P., Kotsinas, A., 436 Liloglou, T., Venere, M., Ditullio, R.A., Jr., Kastrinakis, N.G., Levy, B., Kletsas, D., 437 Yoneta, A., Herlyn, M., Kittas, C., Halazonetis, T.D., 2005. Activation of the DNA 438 damage checkpoint and genomic instability in human precancerous lesions. Nature $439 \quad 434,907-913$.

440 Guha, N., Guyton, K.Z., Loomis, D., Barupal, D.K., 2016. Prioritizing Chemicals for 441 Risk Assessment Using Chemoinformatics: Examples from the IARC Monographs 442 on Pesticides. Environ Health Perspect.

443 Guyton, K.Z., Loomis, D., Grosse, Y., El Ghissassi, F., Benbrahim-Tallaa, L., 444 Guha, N., Scoccianti, C., Mattock, H., Straif, K., International Agency for Research 445 on Cancer Monograph Working Group, I.L.F., 2015. Carcinogenicity of 
446 tetrachlorvinphos, parathion, malathion, diazinon, and glyphosate. Lancet Oncol $447 \quad 16,490-491$.

448 Guyton, K.Z., Loomis, D., Grosse, Y., El Ghissassi, F., Bouvard, V., Benbrahim449 Tallaa, L., Guha, N., Mattock, H., Straif, K., International Agency for Research on 450 Cancer Monograph Working, G., 2016. Carcinogenicity of pentachlorophenol and 451 some related compounds. Lancet Oncol 17, 1637-1638.

452 Hodgson, J.T., McElvenny, D.M., Darnton, A.J., Price, M.J., Peto, J., 2005. The 453 expected burden of mesothelioma mortality in Great Britain from 2002 to 2050 . Br J 454 Cancer 92, 587-593.

455 Hong, M.Y., Hoh, E., Kang, B., DeHamer, R., Kim, J.Y., Lumibao, J., 2017. Fish Oil 456 Contaminated with Persistent Organic Pollutants Induces Colonic Aberrant Crypt 457 Foci Formation and Reduces Antioxidant Enzyme Gene Expression in Rats. J Nutr. 458 Irigaray, P., Belpomme, D., 2010. Basic properties and molecular mechanisms of 459 exogenous chemical carcinogens. Carcinogenesis 31, 135-148.

460 Koifman S., K.R.J., Meyer A., 2002. Human reproductive system disturbances and 461 pesticide exposure in Brazil. Cad Saud Pub 18, 435-445.

462 Landau-Ossondo, M., Rabia, N., Jos-Pelage, J., Marquet, L.M., Isidore, Y., Saint463 Aime, C., Martin, M., Irigaray, P., Belpomme, D., pesticides, A.i.r.g.o., 2009. Why 464 pesticides could be a common cause of prostate and breast cancers in the French 465 Caribbean Island, Martinique. An overview on key mechanisms of pesticide466 induced cancer. Biomedicine \& pharmacotherapy = Biomedecine \& 467 pharmacotherapie 63, 383-395.

468 Lawrence, M.S., Stojanov, P., Polak, P., Kryukov, G.V., Cibulskis, K., Sivachenko, 469 A., Carter, S.L., Stewart, C., Mermel, C.H., Roberts, S.A., Kiezun, A., Hammerman, 
470 P.S., McKenna, A., Drier, Y., Zou, L., Ramos, A.H., Pugh, T.J., Stransky, N., 471 Helman, E., Kim, J., Sougnez, C., Ambrogio, L., Nickerson, E., Shefler, E., Cortes, 472 M.L., Auclair, D., Saksena, G., Voet, D., Noble, M., DiCara, D., Lin, P., 473 Lichtenstein, L., Heiman, D.I., Fennell, T., Imielinski, M., Hernandez, B., Hodis, E., 474 Baca, S., Dulak, A.M., Lohr, J., Landau, D.A., Wu, C.J., Melendez-Zajgla, J., 475 Hidalgo-Miranda, A., Koren, A., McCarroll, S.A., Mora, J., Lee, R.S., Crompton, B., 476 Onofrio, R., Parkin, M., Winckler, W., Ardlie, K., Gabriel, S.B., Roberts, C.W., 477 Biegel, J.A., Stegmaier, K., Bass, A.J., Garraway, L.A., Meyerson, M., Golub, T.R., 478 Gordenin, D.A., Sunyaev, S., Lander, E.S., Getz, G., 2013. Mutational 479 heterogeneity in cancer and the search for new cancer-associated genes. Nature $480 \quad 499,214-218$.

481 Lee, W.J., Sandler, D.P., Blair, A., Samanic, C., Cross, A.J., Alavanja, M.C., 2007. 482 Pesticide use and colorectal cancer risk in the Agricultural Health Study. Int J 483 Cancer 121, 339-346.

484 Lima, E.E., Queiroz, B.L., 2014. Evolution of the deaths registry system in Brazil: associations with changes in the mortality profile, under-registration of death counts, and ill-defined causes of death. Cadernos de saude publica 30, 1721-1730.

487

488

489

490

491

492

493

Lodovici, M., Casalini, C., Briani, C., Dolara, P., 1997. Oxidative liver DNA damage in rats treated with pesticide mixtures. Toxicology $117,55-60$.

Maqbool, F., Mostafalou, S., Bahadar, H., Abdollahi, M., 2016. Review of endocrine disorders associated with environmental toxicants and possible involved mechanisms. Life Sci 145, 265-273.

Matuo, Y.K., Lopes, J.N., Casanova, I.C., Matuo, T., Lopes, J.L., 1992. Organochlorine pesticide residues in human milk in the Ribeirao Preto region, state 
494

495

496

497

498

499

500

501

502

503

504

505

506

507

508

509

510

511

512

513

514

515

516

517

of Sao Paulo, Brazil. Archives of environmental contamination and toxicology 22, 167-175.

Meyer, A., Chrisman, J., Moreira, J.C., Koifman, S., 2003. Cancer mortality among agricultural workers from Serrana Region, state of Rio de Janeiro, Brazil. Environmental research 93, 264-271.

Nagao, M., Sugimura, T., 1993. Carcinogenic factors in food with relevance to colon cancer development. Mutat Res 290, 43-51.

Nebert, D.W., Dalton, T.P., 2006. The role of cytochrome P450 enzymes in endogenous signalling pathways and environmental carcinogenesis. Nat Rev Cancer 6, 947-960.

Parron, T., Requena, M., Hernandez, A.F., Alarcon, R., 2014. Environmental exposure to pesticides and cancer risk in multiple human organ systems. Toxicol Lett 230, 157-165.

Poirier, M.C., 2016. Linking DNA adduct formation and human cancer risk in chemical carcinogenesis. Environ Mol Mutagen 57, 499-507.

Sakita, J.Y., Gasparotto, B., Garcia, S.B., Uyemura, S.A., Kannen, V., 2017. A critical discussion on diet, genomic mutations and repair mechanisms in colon carcinogenesis. Toxicol Lett 265, 106-116.

Siegel, R., Desantis, C., Jemal, A., 2014. Colorectal cancer statistics, 2014. CA Cancer J Clin 64, 104-117.

Soliman, A.S., Smith, M.A., Cooper, S.P., Ismail, K., Khaled, H., Ismail, S., McPherson, R.S., Seifeldin, I.A., Bondy, M.L., 1997. Serum organochlorine pesticide levels in patients with colorectal cancer in Egypt. Archives of environmental health 52, 409-415. 
518

519

520

521

522

523

524

525

527 Torre, L.A., Bray, F., Siegel, R.L., Ferlay, J., Lortet-Tieulent, J., Jemal, A., 2015.

528 Global cancer statistics, 2012. CA Cancer J Clin 65, 87-108.

529 Ulm, K., 1990. A simple method to calculate the confidence interval of a 530 standardized mortality ratio (SMR). Am J Epidemiol 131, 373-375.

531 Uyemura, S.A., Stopper, H., Martin, F.L., Kannen, V., 2017. A Perspective

532 Discussion on Rising Pesticide Levels and Colon Cancer Burden in Brazil.

533 Frontiers in public health 5, 273.

534 Vogelstein, B., Kinzler, K.W., 2015. The Path to Cancer --Three Strikes and You're 535 Out. The New England journal of medicine 373, 1895-1898.

536

537

538

539

Soto, A.M., Sonnenschein, C., 2010. Environmental causes of cancer: endocrine disruptors as carcinogens. Nature reviews. Endocrinology 6, 363-370.

Tellez-Banuelos, M.C., Haramati, J., Franco-Topete, K., Peregrina-Sandoval, J., Franco-Topete, R., Zaitseva, G.P., 2016. Chronic exposure to endosulfan induces inflammation in murine colon via beta-catenin expression and IL-6 production. $\mathrm{J}$ Immunotoxicol 13, 842-849.

Tomasetti, C., Vogelstein, B., 2015. Cancer etiology. Variation in cancer risk among tissues can be explained by the number of stem cell divisions. Science 347, 78-81.

Walker, D.M., Gore, A.C., 2011. Transgenerational neuroendocrine disruption of reproduction. Nature reviews. Endocrinology 7, 197-207.

Wu, S., Powers, S., Zhu, W., Hannun, Y.A., 2016. Substantial contribution of extrinsic risk factors to cancer development. Nature 529, 43-47. 
540 Yi, S.W., 2013. Cancer incidence in Korean Vietnam veterans during 1992-2003:

541 the Korean veterans health study. Journal of preventive medicine and public health

$542=$ Yebang Uihakhoe chi 46, 309-318.

543

544 


\section{Figure Legends}

Fig.1. Smoothed standard mortality rates for CC in the Brazilian male population in each state of the country, as calculated by the Bayesian model.

Fig.2. Smoothed standard mortality rates for CC in the Brazilian female population in each state of the country, as calculated by the Bayesian model.

Fig.3. Heatmaps show the amount of sold pesticide recorded in each Brazilian state by total cultivated area ( $1000 \times$ tonne /hectare) from 2000 to 2012 .

Fig.4. Scatterplots of the relationship in the Brazilian male population between SMR values and the amount of sold pesticide recorded in each state of the country by total cultivated area (1000 x tonne/ hectare) from 2000 to 2012 .

Fig.5. Scatterplots of the relationship in the Brazilian female population between SMR values and the amount of sold pesticide recorded in each state of the country by total cultivated area (1000 x tonne/ hectare) from 2000 to 2012 .

Fig.6. Credible intervals for the effects $\beta_{s t}$ of the amount of sold pesticide on the SMR values for each year $(t)$ and gender $(s)$, obtained from the Bayesian spatiotemporal regression models. 

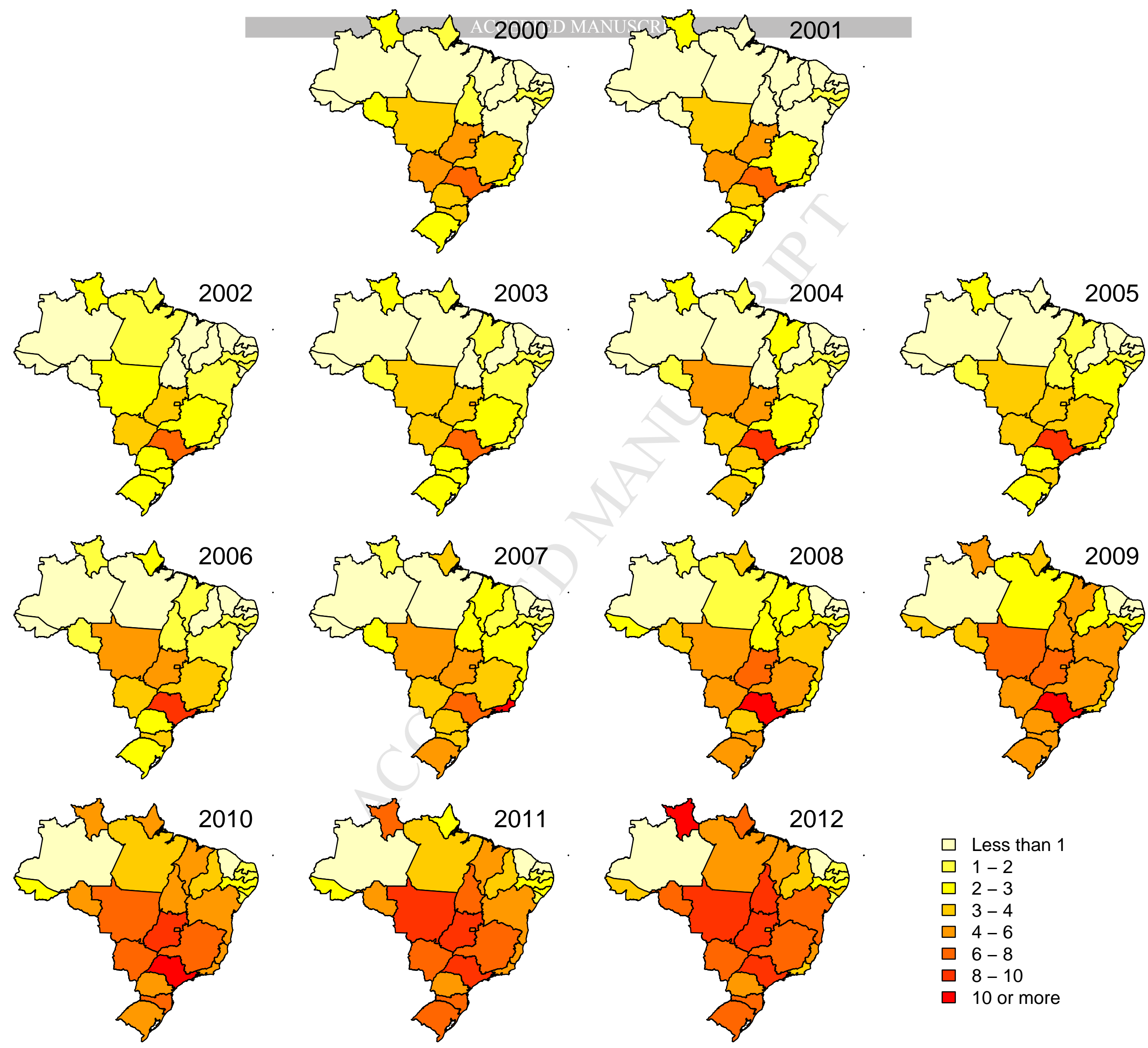

$\square$ Less than 1

$\square 1-2$

$\square 2-3$

$\square \quad 3-4$

$\square \quad 4-6$

$\square \quad 6-8$

$\square \quad 8-10$

$\square 10$ or more 


\section{Highlights}

- Human exposure to xenobiotics occurs worldwide, largely;

- Pesticides may promote cancer risk;

- Brazil is the world major pesticides consumer;

- Colon cancer (CC) mortality is steadily increasing in Brazil;

- We found CC mortality and pesticide levels may be correlated events in Brazil. 